\title{
Accessory Chromosomes in Apples
}

\author{
M. S. Chaudhary ${ }^{1}$ and P. N. Mehra \\ Department of Botany, Panjab University, Chandigarh, India
}

Received March 20, 1973

Occurrence of accessory chromosomes is known in a large number of plants. These were shown to occur in Sorghum (Darlington and Thomas 1941), maize (Randolph 1941), Xanthium taxanum (Berger et al. 1955), Panicum coloratum (Swaminathan 1956), Crepis conyzaefolia (Frost and Östergren 1959), wheat (Moore 1961), Poa alpina (Müntzing 1966), and Phleum nodosum (Frost 1969). These were also reported in Himalayan hard woods (Mehra and Bawa 1968) and in Pterotheca falconeri (Mehra and Mann 1972). However a detailed study has been undertaken in a few species only (Frost 1969).

Apple, though an important fruit crop grown extensively in the $\mathrm{Kulu}$ Valley of India, is comparatively least worked out cytologically. Occurrence of accessory chromosomes in apples has not been reported so far. Therefore it was considered interesting to undertake the morpho-cytological studies in some of the important cultivated apple varieties of the Kulu Valley.

\section{Material and methods}

Plant material used for this study was grown in the Aramgarh orchard at a height of $5000 \mathrm{ft}$ above sea level in the Kulu Valley. The apples are grown over there for many years under constant observation. Cytological data of apple varieties such as the number of accessory chromosomes present and their meiotic behaviour was studied.

The fixation for the meiotic studies was made in acetic alcohol ( 3 parts absolute alcohol and one part glacial acetic acid) and in Carnoy's fixative (100 parts absolute alcohal, 50 parts chloroform, 16 parts glacial acetic acid) the former fixative proved more useful in dissolving the refractive bodies contained in spore mother cell of the apple.

According to Einset et al. (1947), apples are poor cytological material, the chromosomes are small, meiotic stages are not easily located and preparations are rather difficult to interpret". The author, however, could accomplish staining with aceto-carmine containing traces of iron acetate, with good results.

Cytological studies were made on the spot, as well as in the University Botanical Laboratories at Chandigarh. The material which was kept in the fixative or preserved for more than 15 days in 50 percent alcohol become brittle whereas the fresh material tried on the spot proved to be the best.

1 Present address: Associate Professor, Plant Breeding Department, Haryana Agricultural University, Hissar, India. 


\section{Results and disussion}

A comparative study of morphological and cytological investigation were made in two cultivars of apple namely Ambri and Kulu Kenya (Table 1).

Meiosis was studied in these two cultivars. Ambri was found to be diploid



Fig. 1. Normal meiotic bivalents $n=17$ in apple cultivar Ambri.



Fig. 2. Pollen mother cell of apple cultivar Kulu Kenya at M1 showing $171 \mathrm{II}$ and 5 accessories. The accessory chromosomes are lying at the periphery.

with $\mathrm{n}=17$ (Fig. 1). Regular separation of chromosomes was seen at the two poles which led to the formation of normal tetrads but $17 \mathrm{II}+5$ accessory of supernumerary or B chromosomes in a tree of Kulu Kenya apple in Kulu gardens were observed (Fig. 2). The same are absent in other trees of the same variety growing there under 
similar conditions. This is the most interesting cytological investigation which is reported for the first time in fruit trees.

The accessory chromosomes were defined by White (1945) as "elements which are present in some individuals of the population but not in others". Müntzing (1961) observed that "these chromosomes represent more or less incidental addition to the normal chromosome complement".

They differ in size, number, and stainability and can be distinguished from the normal chromosomes, Among the angiospermous families they appear to be common in Gramineae. Accessory chromosomes were first observed in Homopteran insect Metapodium by Wilson (1905). Later studies by Darlington (1937), Håkansson (1945), Fernandes (1946), Ostergren (1947), Melander (1950), Baenziger (1962 a, b) have revealed the presence of these chromosomes in many insects and higher

Table 1. Cytomorphological characters of apple cultivars

\begin{tabular}{|c|c|c|}
\hline Name of the cultivar & Ambri & Kulu Kenya \\
\hline Parentage & Chance seedling in Kashmir Valley. & Chance seedling in Kulu Valley \\
\hline Habit of the tree & $\begin{array}{l}\text { Strong, slow growing, upright and } \\
\text { round headed, comes in bearing after } \\
\text { a long time, i.e. 10-15 years, look } \\
\text { graceful, average bearer. }\end{array}$ & $\begin{array}{l}\text { Very vigorous, upright spread- } \\
\text { ing, round headed, heavy } \\
\text { bearer. }\end{array}$ \\
\hline Flowers & $\begin{array}{l}\text { In clusters of } 5-6 \text { flowers; pedicel } \\
\text { very thin, } 2.00-2.5 \mathrm{~cm} \text { long, densely } \\
\text { hairy; corolla attractive pinkish, } 4.8 \\
-5.0 \mathrm{~cm} \text { in diameter; colour diffused } \\
\text { in petal lines, apex obtuse to emargi- } \\
\text { nate. }\end{array}$ & $\begin{array}{l}\text { In cluster of } 4.5 \text {; pedicel thick, } \\
0.9-2.2 \mathrm{~cm} \text { long, sparsely hairy; } \\
\text { corolla light pink; colour dif- } \\
\text { fused in petals, apex rounded. }\end{array}$ \\
\hline Fruit & $\begin{array}{l}\text { Medium, oblong; skin of shinning } \\
\text { red colour, red streaks on greenish- } \\
\text { yellow back ground of the fruit; } \\
\text { flesh unusually white, not juicy, some } \\
\text { what tough, sweeter than other com- } \\
\text { mercial varieties. } \\
\text { It has long storage life than any other } \\
\text { variety and can be kept till the next } \\
\text { crop is ready. }\end{array}$ & $\begin{array}{l}\text { Medium, roundish, slightly } \\
\text { flattened; skin smooth, cover- } \\
\text { ed entirely, with attractive } \\
\text { bright red stripes; flesh slightly } \\
\text { yellowish, juicy, taste relishing. } \\
\text { It can be used for preparing } \\
\text { liquor. }\end{array}$ \\
\hline Chromosome count & $\mathrm{n}=17$ & $\mathrm{n}=17+5 \mathrm{a}$ \\
\hline
\end{tabular}

plants. Recently Makino (1951) and White (1945) have added a number of plant and animal species possessing these chromosomes. According to the writer's knowledge, this is the first report of accessory chromosomes in apple. These varied in number and size in different mother cells of the same population therefore, represent true accessories. Further, the properties and behaviour exhibited by them during meiosis also point in the same direction.

At metaphase I they take a very light stain with aceto-carmine and are rather small in size. They have neither been observed to pair or divide longitudinally but they are usually orientated to the periphery of the cell. Their irregular distribution can be attributed to a weak centromere compared to the normal bivalent. Morphologically there exists no distinction between the individual possessing the accessory chromosomes and the trees without them. Hence, as first pointed out by Müntzing 
they do not have an important role in the life process of the plant. Their mode of origin could not be studied precisely but it is possible that they might have arisen by fragmentation of the ordinary chromosomes as suggested by Bosemark (1954), Hutchinson and Bashaw (1963).

\section{Summary}

Cytological studies were conducted on two important cultivars of apple with a view to include in future breeding programme. The chromosome behaviour is normal, resulting in well filled pollen grains in the Ambritype. Accessory chromosomes with members of the normal 17 chromosome complement were noted in the variety Kulu Kenya. This appears to be the first report of its kind in temperate fruit trees. Morphologically there exists no distinction between the individual possessing the accessory chromosomes and the trees without them.

\section{Literature cited}

Baenziger, H. 1962. Supernumerary chromosomes in diploid and tetralpoid forms of crested wheatgrass. Can. J. Botany 40: 549-561.

- and Knowles, R. P. 1962. Agronomic significance of supernumerary chromosomes in crested wheatgrass. Crop Sci. 2: 417-420.

Bosemark, N. O. 1954. On accessory chromsosomes in Festuca pratensis I. Cytologiacl investigations. Hereditas $40: 346-376$.

Berger, C. A., McMaron, R. M. and Witkus, E. R. 1955. The cytology of Xanthisma taxanum. Bull. Torrey Bot. Club 82: 377-382.

Darlington, C. D. 1937b. Chromosome behavior and structural hybridity in the Tradescantiae. 11. Jour. Genetics 35: 259-280.

- and Thomas, P. T. 1941. Morbid mitosis and the activity of inert chromosomes in Sorghum. Proc. Roy. Soc. Lond. 130: 127-149.

Einset, J., and Barbara, Imhofe 1947. Chromosome numbers of apple varieties and sports I. Proc. Amer. Soc. Hort. Sci. 50: 45-50.

Fernandes, A. 1946. Sur le comportement des chromosomes sur numeraires heterochromatiques pendant la meiose. Bol. Soc. Broteriana 20: 93-155.

Frost, S. 1969a. The inheritance of accessory chromosomes in plants especially in Ranunculus acris and Phleum nodosum. Hereditas 61: 317-326.

- 1969b. The meiotic behaviour of the accessory chromosomes in Ranunculus acris. Hereditas 62: 421-425.

- and Östergren, G. 1959. Crepis pannonica and Crepis Conzaefolia, two species having accessory chromosomes. Hereditas 45: 211-214.

Östergren, G. 1947. Heterochromatic B-chromosomes in Anthonanthum. Hereditas 33: 261296.

Håkansson, A. 1945. Überzählige Chromosomen in einer Rasse von Godetia mutans Hiroth. Bot. Not. 1: 1-19.

Hutchinson, D. and Bashaw, E. C. 1963. Accessory chromosomes in Panicum coloratum. Can. J. Cenet. Cytol, 5: 281-289.

Makino, S. 1951. An Atlas of the Chromosome Numbers in Animals. Iowa State College press, Ames: 290 pp.

Mehra, P. N. and Bawa, K. S. 1968. Accessory chromosomes in Himalayan hardwoods. Chromosoma 25: 90-95.

- and Mann, S. K. 1972. Accessory chromosomes in Pterotheca falconeri. The Nucleus 15: 123-133. 
Melander, Y. 1950. Accessory chromosomes in animals, especially in Polycelis tennis. Hereditas 36: $19-37$.

Moore, R. J. 1961. Behaviour of accessory chromosomes in Secale cereale and in a Secale cereale $\times$ montamum hybrid. Can, J. and Genet. Cytol. 3: 283-288.

Müntzing, A. 1961. Genetic Research, LTs Forlag, Stockholm, Sweden.

- 1966. Accessory chromosomes. Bull. Bot. Soc. Bengal 10: 1-15.

Randolph, L. F. 1941. Genetic characteristics of the B-chromosomes in maize. Genetics 26: 608-631.

Swaminathan, M. S., and Nath, J. 1956. B-chromosomes in Panicum coloratum. Curr. Sci. 25: 123-124.

White, M. J. D. 1945. Animal Cytology and Evolution. University Press. Cambridge.

Wilson, E. B. 1905 . The paired microchromosomes, idiochromosomes and heterotropic chromosomes in Hemiptera. J. Exp. Zool. 2: 507-545. 